\title{
Krizni menadžment u Katoličkoj crkvi
}

\section{Izazovi institucionalne komunikacije}

\author{
Davor Trbušić*
}

\begin{abstract}
Sažetak
Katolička crkva danas nije pošteđena nepredviđenih događaja koji uzrokuju krizne situacije. Takve intenzivne dinamike u posljednjih nekoliko desetljeća ukazuju na nužnost primjene profesionalnih načela kriznoga komuniciranja na institucionalnoj razini Crkve. Stoga ovaj rad analizira ulogu biskupijskih ureda za komunikaciju tijekom kriznih situacija te ujedno nudi i neke preporuke komunikatorima pri njihovu upravljanju, kako bi se ublažile negativne posljedice po organizacijski imidž te unaprijedili procesi organizacijskoga učenja u postkriznoj fazi. Autor ukazuje na potrebu usvajanja kulture odgovornosti među crkvenim poglavarima te promišlja o tome kako i najteži oblici kriza mogu postati prilika za stvaranje perspektivne vizije, ali i za navještaj evanđeoske poruke.
\end{abstract}

Ključne riječi: krizni menadžment; Katolička crkva; crkvena komunikacija

\section{Uvod}

Nesumnjivo je da je Katolička crkva unazad nekoliko desetljeća postala svjesna kako je pozvana aktivno sudjelovati u suvremenom svijetu komunikacija. Njezina zauzetost na tom području podrazumijeva stvaranje novih oblika komunikacije i korištenje naprednih komunikacijskih alata i tehnologija.

Posljedično tomu, Katolička crkva i njezini predstavnici često postaju središtima medijske i javne pozornosti, napose tijekom kriznih situacija. Uvriježena tendencija da krizni menadžment bude organizacijski imperativ vrijedi i za Katoličku crkvu, koja bi, poučena iskustvom skandala posljednjih nekoliko desetljeća, trebala razmišljati o implementaciji odgovarajućih taktika za rješavanje krize na institucionalnoj razini.

Organizacijske strukture u Crkvi moraju biti svjesne kako skandali uistinu postoje i da oni ne bi smjeli biti ignorirani. Stoga je i crkvena komunikacija u

* Davor Trbušić, mag. comm, Fakultet hrvatskih studija, Sveučilište u Zagrebu. Adresa: Borongajska cesta 83d, 10000 Zagreb, Hrvatska. ORCID iD: https://orcid.org/0000-0001-9896-8412. E-adresa:dtrbusic@hrstud.hr 
kriznim situacijama posljednjih godina postala predmet različitih društvenih istraživanja, kao i proučavanja praktičara odnosa s javnošću. Jedan od takvih analiziranih slučajeva odreknuce je od službe pape Benedikta XVI. 2013. godine, koji je pokazao da su stručnjaci za odnose s javnošću u tiskovnom uredu Svete Stolice, »primjenjujući u konkretnoj situaciji suvremene komunikološke spoznaje i koristeći raspoložive komunikacijske alate, uspješno upravljali krizom « (Milas i Galić, 2014, 781).

Unatoč činjenici da stajališta crkvenoga učiteljstva ističu potrebu planiranja komunikacije pri provedbi svakoga pastoralnoga plana na razini biskupija i biskupskih konferencija, ipak svjedočimo nedostatku konkretnih strategija za rješavanje kriznih situacija, koje su dio crkvene svakodnevice još od njezina postanka.

\section{Krizni menadžment — definicije i ključni pojmovi}

Ne postoji jedinstveno gledište pri definiranju krize. Prema Yagu de la Ciervi, kriza označava »bitnu promjenu društvenih okolnosti o kojoj može ovisiti sâmo postojanje određene institucije « (Cierva, 2014, 55). Kathleen Fearn-Banks definira krizu kao "pojavu s potencijalno negativnim ishodom koji utječe na organizaciju, tvrtku ili industriju, kao i na njezine javnosti, proizvode, usluge ili reputaciju « (Wilcox et al., 2012, 258). Londonska škola za odnose s javnošću (LSPR) pod krizom podrazumijeva »nepredviđeni događaj koji utječe na sigurnost ljudi, okoliš, proizvode ili ugled pojedine organizacije« (Novak, 2001, 28).

Definicije različitih autora uglavnom se podudaraju i naglašavaju iste elemente. Mnoge od njih objašnjavaju kako su većini definicija krize zajednička tri elementa: tvrdnja kako su krize atipični događaji koji se mogu predvidjeti, ali su ipak uvijek neočekivani kad se dogode; činjenica da krize mogu uzrokovati štetu organizacijama, ali i pojedincima unutar organizacija; teza da kriza prisiljava organizaciju na komuniciranje s različitim skupinama radi ograničavanja opasnosti koju može prouzročiti (Jugo, 2017).

Znakovito je kako pojedini teoretičari pri definiranju krize ostavljaju prostor za afirmativnu interpretaciju toga neočekivanoga događaja unutar organizacije. Primjerice navedena definicija Fearn-Banks govori o potencijalno negativnom ishodu, ne tvrdeći a priori kako je riječ o nepoželjnom događaju. Pogledamo li samo etimologiju riječi kriza, vidimo da ona dolazi od grčke riječi krisis i krinein, koje su u antičkoj Grčkoj označavali medicinski termin za opisivanje točke preokreta u nekoj bolesti, odnosno termin koji se rabio u značenju »suditi, razdvajati, odlučivati« (Sellnow, Seeger prema Jugo, 2017, 20).

Korporativnim rječnikom, kriza je prilika da se promijeni način razmišljanja u organizaciji: »definiraju se potrebne organizacijske promjene, jača vodstvo organizacije, poboljšavaju se sustavi nadzora « (Novak, 2001, 171), a osim toga kriza otvara i priliku za »organizacijsko učenje, etičku komunikaciju, perspektivnu viziju i uspostavljanje prave organizacijske retorike «(Ulmer, Seeger, Sellnow prema Jugo, 2017, 222). 
Krizne situacije nije jednostavno klasificirati po vrsti i naravi. Teoretičari odnosa s javnošću ističu četiri osnovne skupine organizacija koje su najizloženije kriznim situacijama. To su: veliki zrakoplovni prijevoznici; kemijski i naftni proizvođači i prodavači; proizvođači hrane; pružatelji financijskih usluga (Luecke, 2005).

Kada je riječ o uzrocima krize, suvremena literatura koja proučava krizno komuniciranje razlikuje vanjske i unutrašnje uzroke krize. Vanjski su uzroci oni koji nastaju u okolini izvan organizacije i na koje ona nema velik utjecaj (Jugo, 2017), a unutrašnji uzroci često nisu vidljivi onima koji krizu proučavaju izvan organizacijskoga sustava i često se "skrivaju” u samoj organizaciji (Novak, 2001). Potonja tvrdnja ima i empirijski dokaz jer, prema istraživanju Instituta za krizni menadžment 2010. godine, više od $80 \%$ kriznih situacija prouzročeno je unutrašnjim ljudskim čimbenikom (Jugo, 2017).

Naposljetku, bez obzira na uzrok krize, naglasak je uvijek na tome kako određena organizacija ili institucija odgovara na krizu (Cierva, 2014). Sudeći po navedenim definicijama krize teoretičara odnosa s javnošću, može se zaključiti kako je u srcu krize - institucija. Kada kriza nastupi, postojanost i stabilnost institucije mogu biti izloženi egzistencijalnomu riziku, a takve iznenadne i potencijalno opasne situacije ne zaobilaze ni Katoličku crkvu na njezinoj organizacijskoj razini.

\section{Krizne situacije kao dio svakodnevice u Katoličkoj crkvi}

Kada je 2011. godine nizozemski novinar Ekke Overbeek upitao glasnogovornika biskupske konferencije Poljske postoje li u Crkvi u Poljskoj naznake da bi se primjeri seksualnoga zlostavljanja maloljetnika mogli pojaviti i među tamošnjim klerom, on je odgovorio kako taj problem zasigurno u Poljskoj ne postoji jer su narod s duboko ukorijenjenim katoličkim identitetom te da se nikako ne mogu usporediti s Irskom ili Sjedinjenim Američkim Državama, koji su već bili pogođeni takvim skandalima. Dvije godine kasnije, u siječnju 2013. godine, isti nizozemski novinar objavio je knjigu naslovljenu Be afraid: Victims of Paedophilia by the Catholic Church Speak ("Strahujte: Žrtve pedofilije u Katoličkoj crkvi govore") o 27 slučajeva zlostavljanja i optužaba protiv poljskih katoličkih biskupa, koji su pedofilska zlodjela navodno zataškali. Poljska biskupska konferencija reagirala je na objavljenu knjigu ocijenivši ju »šupljom kao švicarski sir«, te je ujedno podsjetila na jasne smjernice za postupanje u slučajevima seksualnoga zlostavljanja koje su poljski biskupi donijeli na svojem zasjedanju u ožujku 2012. godine (Anon., 2013).

Taj slučaj jasno navodi na dva zaključka: »nikad ne reci nikad «i »skandali postoje — ne treba ih poricati«, nego o njima ozbiljno razmišljati i ne ih hipotetski isključivati unaprijed kao da nisu mogući.

Posljednje desetljeće u Katoličkoj crkvi u Europi i svijetu obilježile su različite krizne situacije. U nastavku navodimo samo neke, za koje se može kazati kako su imale određeni odjek u međunarodnoj i nacionalnoj, hrvatskoj javnosti: 
a) Nadbiskup Poznana Juliusz Paetz optužen je 2002. godine zbog neprimjerenih radnji povezanih sa sjemeništarcima te je morao odstupiti (Tagliabue, 2002).

b) Svećenik Zagrebačke nadbiskupije suspendiran je 2011. godine nakon što je policija pronašla uznemirujući, pedofilski sadržaj na njegovu računalu (Tiskovni ured Zagrebačke nadbiskupije, 2011).

c) Godine 2009. objavljeni su rezultati istrage seksualnoga zlostavljanja maloljetnika u biskupiji Dublin, tzv. Murphyjevo i Ryanovo izvješće (Commission of Investigation, 2009).

d) Godine 2013. Crkvu u Sloveniji pogodila je financijska kriza: Mariborska biskupija bankrotirala je i dvojica slovenskih biskupa Anton Stres i Marjan Turnšek bili su primorani odstupiti. Ta je kriza prema nekim analitičarima ocijenjena kao najveća financijska katastrofa u povijesti Katoličke crkve (Allen, 2015).

e) svećenik Zadarske nadbiskupije don Nedjeljko Ivanov 2014. optužen je za zlostavljanje maloljetnika od 1983. do 1991. godine (Zadarska nadbiskupija, 2014).

f) Skandal Vatileaks, u kojem je sobar pape Benedikta XVI. bio optužen za krađu povjerljivih dokumenata iz Vatikana. O toj kriznoj situaciji papa Benedikt XVI. prvi je put javno progovorio 30. svibnja 2012. ističući kako su mu »nedavna zbivanja u vezi s Kurijom i njegovim suradnicima ispunili srce tugom, ali da nikada nisu umanjila čvrstu sigurnost da Crkvu, usprkos ljudskoj slabosti, poteškoćama i iskušenjima, vodi Duh Sveti« (Benedikt XVI., 2012).

g) Trideset četvero čileanskih biskupa ponudilo je 2018. godine ostavku te zatražilo oprost zbog boli koju su svojim ozbiljnim grješkama i propustima prouzročili žrtvama svećeničkoga seksualnoga zlostavljanja (Bordoni, 2018).

h) Godine 2018. predstavljena je studija o zlostavljanjima u Katoličkoj crkvi u Njemačkoj (Centofanti i Žaja, 2018).

Spomenuti skandal u Irskoj prouzročio je golemu štetu Katoličkoj crkvi u Irskoj, ali i u cijelom svijetu. Procjenjuje se, naime, da Crkva u Irskoj bilježi dva razdoblja u recentnoj povijesti u kojima je primijećen bitan pad broja vjernika koji jednom tjedno prisustvuju svetoj misi. Riječ je o 2009. godini, kada se je broj vjernika smanjio za 6,4\%, i 2011. godini, kada se je broj smanjio za 7,4\%. Navedena razdoblja u podudarnosti su s trima izvješćima o rezultatima istrage seksualnoga zlostavljanja maloljetnika — već spomenutim Murphyjevim i Ryanovim 2009. te izvješćem o rezultatima istrage u irskoj biskupiji Cloyne iz 2011. godine (McGarry, 2016).

Osim toga, taj je skandal ostao upamćen i po pastoralnom pismu pape Benedikta XVI. katolicima u Irskoj, kojim je poglavar Katoličke crkve pokazao spremnost na suočavanje s jednom od najdubljih kriza u novijoj povijesti te institucije. Papa Benedikt XVI. ispričao se je i izrazio žaljenje zbog seksualnih zlostavljanja maloljetnika koja su počinili svećenici, ističući u pismu kako je »razumljivo da s mukom opraštate [irski katolici, op. a.] ili da se mirite s Crkvom. Otvoreno priznajem u ime Crkve da svi osjećamo sram i grižnju savjesti, ujedno vas molim da ne gubite nadu« (Benedikt XVI., 2010a). 
Skandali seksualnoga zlostavljanja maloljetnika u Katoličkoj crkvi ne smiju biti olako shvaćeni, posebice nakon izvješća Svete Stolice predstavljeno odboru Ujedinjenih naroda protiv mučenja 2014. godine. Stalni promatrač Svete Stolice pri UN-u Silvano Maria Tomasi kazao je kako je u razdoblju od 2004. do 2013. godine Kongregacija za nauk vjere zaprimila točno 3.420 izvješća o slučajevima seksualnoga zlostavljanja maloljetnika koja su počinili svećenici. Od tih 3.420, klerički stalež oduzet je 848 svećenika, što se smatra najstrožom kaznom, a na ostalih 2.572 svećenika primijenjeni su drugi oblici crkvenih kazni (World Organization Against Torture, 2014).

Sveta Stolica ratificirala je Konvenciju o pravima djeteta 1990. godine, a četiri godine kasnije podnijela je svoje prvo izvješće (Ujedinjeni narodi, 1996). Od tada nije podnijela nijedno izvješće, osim onoga iz 2012. godine, kada je pod pritiskom javnosti zbog seksualnih zlostavljanja maloljetnika u 2010. godini u Europi i svijetu popustila pritisku.

Odgovarajući na kritike upućene od strane odbora Ujedinjenih naroda, zaduženoga za nadzor pri rješavanju problema svećeničkoga seksualnoga zlostavljanja, glavni tužitelj Svete Stolice za seksualne zločine Charles Scicluna rekao je: »Sveta Stolica je shvatila. Ne mogu reći je li prekasno ili nije. No postoje određene stvari koje trebaju biti učinjene drugačije« (Winfield, 2014).

Bilo je nedvojbeno da su ti nemili i izrazito teški trenutci pogodili u sâmo srce Katoličke crkve. U intervjuu s njemačkim novinarom Peterom Seewaldom, papa Benedikt XVI. izjavio je: »Da, to je velika kriza i to se mora reći. Bilo je to potresno za sve nas. Odjednom toliko prljavštine. Bilo je doista poput vulkanskoga kratera iz kojega je odjednom izišao golem oblak prljavštine, sve potamnio i zacrnio, tako da se odjednom poglavito svećeništvo pojavilo kao mjesto sramote te je svaki svećenik bio pod sumnjom da je i on jedan od njih « (Benedikt XVI., 2010b, 38).

\section{Uloga biskupijskoga ureda za komunikaciju i njegovih zaposlenika za vrijeme krize}

Kao što smo do sada primijetili, a Cutlip, Center i Broom potvrđuju, Crkva nije imuna na krizu u odnosima s javnošću, stoga ne čudi činjenica da sve češće zapošljava profesionalne komunikatore pomoću kojih spremnije reagira na krizu, upućuje strateške poruke, poboljšava svoj imidž te privlači vjernike (Broom, 2010).

Na razini Katoličke crkve, odnosno biskupija i nadbiskupija, stručna i operativna tijela zadužena za komunikaciju i djelovanje na medijskom području nazvani su tiskovni uredi. Ukratko, zadaće su tih ureda »skrb o svim vidicima medijskog djelovanja unutar biskupije, povezivanje u usmjeravanje župnih medijskih nastojanja, suradnja s ostalim crkvenim institucijama, kao i s vodećim nacionalnim medijskim crkvenim ustanovama, surađivati s javnim medijima, te sudjelovati u komunikaciji i zainteresiranima posredovati informacije o općoj i mjesnoj Crkvi 
po načelu supsidijarnosti u ozračju dijaloga i međusobnog poštovanja « (Trbušić i Labaš, 2015, 146).

Kada Crkva govori o odnosima s javnošću, misli na aktivnu komunikaciju sa zajednicom pomoću svjetovnih i crkvenih medija. Pastoralna instrukcija Aetatis novae, objavljena 1992. za vrijeme pontifikata Ivana Pavla II., u dijelu o elementima pastoralnoga plana za društvene komunikacije (br. 31) navodi da »uključujući spremnost na komuniciranje vrijednosti Evanđelja, Crkva mora uložiti veliki napor da njezina slika u javnosti bude odraz Isusa Krista« (Papinsko vijeće za komunikaciju, 1992). Premda u Aetatis novae, kao ni u ostalim dosad objavljenim crkvenim dokumentima, nisu izričito spomenute konkretne zadaće ureda za komunikacije u kontekstu kriznoga menadžmenta, u toj je instrukciji predloženo da takvi uredi unutar biskupija imaju odgovarajuće ljudske i materijalne resurse kako bi mogla biti ostvarena kvalitetna komunikacija između Crkve i zajednice, čemu bez sumnje doprinosi i uspješno upravljanje kriznim situacijama.

\subsection{Ključni preduvjeti za uspješno rješavanje krizne situacije}

Slično kao s bolešću, kriza se može prevenirati. Dok se pokušavaju planirati sve potencijalne mogućnosti, »mnogo je realnije razmišljati o krizi kao elementu rizika koji se može predvidjeti ili koji može neočekivano iznenaditi« (Richardson i Laville, 2010, 88).

Pritom valja istaknuti kako svaka krizna situacija ima svoj životni ciklus, koji se sastoji od tri faze: predkrizne, krizne i postkrizne faze. U toj prvoj, možda i najvažnijoj fazi ključno je detektirati signale, jer »većina kriza odašilje različite rane znakove upozorenja koji omogućuju da se potpuno spriječi kriza i sve njezine negativne posljedice « (Jugo, 2017, 81). Prema istraživanju Instituta za krizni menadžment, 67\% kriznih situacija koje su se u svijetu dogodile tijekom 2018. godine ocijenjeno je kao tinjajuće, odnosno one koje su već ranije davale znakove upozorenja, no nisu na vrijeme prevenirane (Institute for Crisis Management, 2018).

U predkriznoj fazi uputno je također sastaviti krizni komunikacijski plan, koji nije čarobno osiguranje u službi zaštite organizacije od krize, no itekako doprinosi izbjegavanju trošenja vremena na pribavljanje općenitih informacija koje su bile poznate i prije krize te vodstvo organizacije lišava ad hoc odlučivanja tko će što raditi i kojim će se redom provoditi planirane aktivnosti (Jugo, 2017).

Kada je riječ o organizacijskoj razini Crkve, prije rješavanja svake krizne situacije potrebno je suočiti se s nekoliko vrsta mitova koji dovode do određenih mentaliteta često prisutnih među crkvenim poglavarima. Takvi mitovi i mentaliteti nerijetko su prepreka za uspješno upravljanje kriznim situacijama.

Prvi je mit da će vjernici biti zaprepašteni ako saznaju za skandal u Crkvi. Takav način razmišljanja osudio je i papa Franjo zaključujući susret Zaštita maloljetnika u Crkvi, koji se je u veljači 2019. godine održao u Vatikanu: »Zlostavljanje se nikad ne smije prikrivati (kako je često bio slučaj u prošlosti) ili ne shvaćati dovoljno ozbiljno, jer prikrivanje zlostavljanja potiče širenje zla i stvara novu razinu skandala« (Franjo, 2019). 
Prikrivanje o kojem govori papa Franjo dovelo je do ranije spomenutih skandala u Irskoj i SAD-u, a razlog je u činjenici da neki crkveni poglavari ni pod koju cijenu ne žele da sablazan iziđe u javnost. Štoviše, mnogi su prezbiteri ili redovnici, koje nazivaju i "pedofilski lovci«, smišljali vrlo domišljate strategije kako bi njihovi prekršaji ostali tajni (Sarah i Diat, 2016, 301-302). Kako ističe Josip Šalković, u nekim su partikularnim Crkvama pojedini ordinariji (usp. CIC kan. 134 §1) pogriješili kad su se, podcjenjujući ozbiljnost činjenica (primjerice obavijest o počinjenom kažnjivom djelu) ograničili na premještaj klerika (usp. CIC kann. 190-191) iz jedne crkvene službe na drugu (ili iz jedne župe na drugu). »Takvi postupci nisu bili ispravan pravni put u ostvarenju pravednosti pa je Sveta Stolica 2001., zbog težine kažnjivoga djela, odlučila prisvojiti pravo odlučivanja za ova kaznena djela« (Šalković, 2012, 367).

Zlatno je pravilo svake, pa i krizne, komunikacije nikada ne reći laž, kako nas uči i Paul Grice, nego uvijek govoriti istinu. Čak i evanđelje jasno govori: »Istina ce vas osloboditi« (Iv 8,32). Prema Američkom društvu za odnose s javnošću iskrenost je jedan od šest ključnih postulata neophodnih za profesionalno bavljenje odnosima s javnošću, uključujući odvažnost u zastupanju stavova, stručnost, neovisnost, odanost i poštenje (Public Relations Society of America, s. a.).

Drugi rašireni mit o kojem valja voditi računa mišljenje je crkvenih poglavara da se skandal nikada neće dogoditi u njihovoj lokalnoj Crkvi. Upitan o tome zašto razotkriveni slučajevi u Americi i Irskoj nisu uzeti kao povod da ih se odmah istraži i u drugim zemljama, papa Benedikt XVI. odgovorio je: »Je li tada zadaća Rima bila da svim zemljama samo kaže: vidite je li tako i kod vas? Možda smo to trebali učiniti« (Benedikt XVI., 2010b, 41-42). Slično je i s poljskim slučajem. U jeku premijernoga prikazivanja dvosatnoga dokumentarnoga filma braće Sekielski pod naslovom Samo ne reci nikomu, koji govori o pedofilskim skandalima u Katoličkoj crkvi u Poljskoj, politički komentator Lukasz Lipinski istaknuo je kako je Crkva u Poljskoj dugo godina mislila i govorila da se takvi slučajevi događaju »negdje na Zapadu«, no ne i u Poljskoj (Shotter i Huber, 2019).

Treći i posljednji mit odnosi se na razumijevanje medija tijekom kriznih situacija. Istina je da su neki mediji sa svojom unaprijed pripremljenom agendom neprijateljski raspoloženi prema Crkvi. Istraživanje iz 2011. godine, čiji je cilj bio istražiti način i kvalitetu medijskoga izvještavanja hrvatskih dnevnih novina o zlostavljanjima u katoličkim odgojnim ustanovama u Irskoj, pokazalo je da su »čitatelji u hrvatskim dnevnim novinama lako mogli (p)ostati dezinformirani, bez detaljnog uvida u pozadinu slučaja, uskraćeni za drugu stranu priče, ali su ujedno mogli vidjeti identitet osumnjičenih, što nije bilo u skladu s etičkim kodeksima i profesionalnim pravilima, a u nekim slučajevima radilo se i o izravnom kršenju zakona (Labaš et al., 2012, 311).

Ipak, optuživati medije zato što izvještavaju o krizi nije preporučena praksa. O tome govori i papa Benedikt XVI., naglašavajući da je prilikom medijskoga izvještavanja o pedofilskim skandalima postojala »radost u razgolićavanju i što većem ocrnjivanju Crkve, no dok je god u pitanju istina, moramo biti zahvalni za svako izvješćivanje« (Benedikt XVI., 2010b, 42). 
Također, važno je razlikovati moralnu paniku od stvarne krizne situacije. Moralna panika vrsta je medijske manipulacije čiji je cilj diskreditirati organizaciju, u ovom slučaju Katoličku crkvu. Ako je riječ o manipulaciji, valja identificirati napadače, obraniti se od napada i održavati stanje kakvo je i bilo dotad.

\subsection{Neka načela i preporuke komunikatorima pri upravljanju kriznim situacijama u Crkvi}

Kada kriza nastupi, zaposlenici tiskovnoga ureda i glasnogovornik koji je zadužen za komuniciranje ključnih poruka trebali bi se pridržavati načela koja navodimo u nastavku rada.

Provođenje dobrih politika prvo je načelo u nizu, a ono podrazumijeva odabir odgovarajuće osobe zadužene za komunikaciju. Cilj je institucionalne crkvene komunikacije »služiti Crkvi (instituciji) i njezinoj poruci« (La Porte, 2009, 239), što bi svaki komunikator trebao imati na umu, pa i tijekom kriznih situacija. Kada je Jeanette De Melo, direktorica komunikacija i glasnogovornica nadbiskupije Denver upitala svojega biskupa što se od nje očekuje, on joj je odgovorio: »Ništa manje od savršenstva « (Puškarić, 2015, 34). Biskupove riječi samo su dokaz tvrdnji da je stručna osoba zadužena za komunikacije unutar biskupije pozvana uložiti velike napore kako bi uistinu komunicirala poruku Crkve, njezin identitet i vrijednosti.

Nadalje, krizna situacija ne može se prevladati bez kriznoga tima i prikupljanja svih relevantnih informacija. Glasnogovornik ili osoba zadužena za rješavanje krizne situacije ne može biti netko tko će samo komunicirati instruirane i već pripremljene poruke, nego mora biti uključena u cjelokupni proces. Stoga krizni tim obično uključuje stručnjake iz odnosa s javnošću i komunikacija, prava, sigurnosti, poslovanja, financija i ljudskih potencijala. »Pritom struktura tima može varirati ovisno o vrsti krize s kojom se organizacija suočava« (Jugo, 2017, 136). Uvjet je za uspješno rješavanje krizne situacije i učinkovita interna komunikacija. Prema Zoranu Tomiću (2008) dobri odnosi s javnošću počinju kod kuće, točnije unutar organizacije, što internu komunikaciju često čini izazovnijom nego eksternu.

Treće, neophodna je uporaba različitih medijskih kanala za odašiljanje ključnih poruka i komuniciranje druge strane priče. Preduvjet je za učinkovite odnose s medijima poznavanje medija. Kao što ističe Tomić, »odnosi s medijima su najvidljiviji dio odnosa s javnošću, koji podrazumijevaju umijeće rada s pojedinim medijima, poznavanje tehnologije rada, prilagođavanje svojih materijala pojedinim medijima, poštivanje rokova i slično (Tomić, 2008, 268).

Svakako je preporučljivo korištenje više medijskih kanala — od onih tradicionalnih pa do društvenih mreža, koje su glavni komunikacijski kanali tijekom kriznih situacija, no to ne znači da ostale valja zanemariti (Cierva, 2014). Novi digitalni mediji u tolikoj su mjeri postali dio modernoga društva da teoretičari medija sve češće raspravljaju o digitalnoj kulturi. Ona je, kako tvrdi Nada Zgrabljić Rotar (2011, 38), »dio kulture društva, dio kulturne politike društva, koja označava proces transformacije same ideje kulture u društvu«. 
Kako to izgleda u praksi, možda je najvidljivije na Twitteru, društvenoj mreži koja se temelji na brzim i kratkim aktualnim informacijama. Novinari koji su aktivni na toj društvenoj mreži posreduju informacije s mjesta događaja, što omogućava publici osjećaj visoke involviranosti, tj. uključenosti u sam događaj. Budući da su društvene mreže idealne platforme za brzo dijeljenje sadržaja kao što su fotografije, poveznice ili video uradci, one stvaraju tzv. ambijentalno novinarstvo. Alfred Hermida $(2012,311)$ ambijentalno novinarstvo definira kao »novinarstvo koje se oslanja na nove komunikacijske tehnologije, a koje nužno karakterizira neposrednost i trenutačnost. Novinarstvo tako postaje fragmentirano, sveprisutno i ukorijenjeno u svakodnevna medijska iskustva korisnika «.

Ne čudi stoga da su praktičari odnosa s javnošću svjesni da »društvene mreže mogu stvoriti dodatnu kriznu situaciju zbog nemogućnosti osiguravanja traženih informacija « (Jugo, 2017, 191), te da kao najveću pogrešku koju stručnjak u odnosima s javnošću može učiniti ističu ignoriranje onoga što se događa na Internetu (Theaker prema Jugo, 2017, 190).

Zaključna je preporuka komunikatorima da tijekom kriznih situacija iskažu emocije i suosjećanje. Istraživanja su pokazala da glasnogovornik koji izrazi iskrenu empatiju tijekom krizne situacije ostvaruje bolju povezanost s publikom i primateljem informacije, a posljedično tomu uspješnije i komunicira (Cierva, 2014). Osim nedostatka ljudskosti, česta je pogreška u kriznim situacijama, kada je slučaj seksualnoga zlostavljanja maloljetnika posrijedi, ponuditi novčanu naknadu žrtvama zločina. Umjesto novca, čini se prihvatljivijim težiti istini, priznanju nedjela, isprici i kajanju.

\section{Skandali u Crkvi: prilika za organizacijsko učenje i perspektivnu viziju}

Kada su jednom prigodom nadbiskupa Pertha Barryja Hickeyja upitali koji je cilj biskupijskoga ureda za komunikacije, odgovorio je: obraćenje. Ustvrdio je kako zadaća ureda nije primarno apologija vjere, poboljšanje imidža i reputacije Crkve ili pak diplomatsko rješavanje skandala, nego je ona isključivo usmjerena obraćenju Kristu (Puškarić, 2015, 48-49).

Nadbiskup je Hickey na tragu smjernica crkvenih dokumenata, napose $A e$ tatis novae - već spomenute pastoralne instrukcije koja jasno ističe bit poslanja Crkve: komunikaciju čiji je krajnji cilj evangelizacija (Skoko i Gusić, 2013, 197). Dakle, zadaća biskupijskoga ureda za komunikacije nije isključivo krizna komunikacija, nego »surađivati s javnim medijima, sudjelovati u komunikaciji i zainteresiranima posredovati informacije o općoj i mjesnoj Crkvi« (Hrvatska biskupska konferencija, 2006, 20), promicati pozitivne inicijative i opće dobro, ukratko — graditi odnose s javnošću, što može bitno utjecati na sprječavanje potencijalnih kriznih situacija.

Nadbiskupove riječi otvaraju potpuno novu perspektivu za razumijevanje krizne situacije kao prilike, a ne kao prijetnje. Isto vrijedi i za Katoličku crkvu. Kako 
bismo prikazali što sve ona može naučiti iz vlastitih kriza, ukratko ćemo analizirati posljedice skandala seksualnoga zlostavljanja maloljetnika — vjerojatno i najtežega oblika krizne situacije za Crkvu.

Prije svega treba istaknuti da prijavljivanjem zlostavljanja žrtva ne postaje neprijatelj. Također je važno da, kada se takvi skandali dogode, crkveni poglavari, kao i osobe zadužene za komunikaciju, ne smiju uspoređivati te zločine s istima ili sličnima učinjenim u drugim društvenim skupinama. Pokušaj umanjivanja značenja takvoga zločina mogao se uočiti odmah nakon objave izvješća UN-ova Odbora za prava djeteta. Čak su se i u Hrvatskoj, doduše ne od službenih crkvenih institucija ni predstavnika Crkve, pojavili pokušaji da se objasni kako pedofilija u Katoličkoj crkvi u usporedbi s drugim vjerskim zajednicama nije tako čest slučaj (Šola, 2014).

Premda je ta tvrdnja istinita, to nije dostatan argument $u$ raspravi jer $\mathrm{i}$ »jedan takav slučaj zlostavljanja sam po sebi predstavlja užas i potrebno mu je pristupiti s najvećom ozbiljnošću « (Franjo, 2019). Primjerice, kriminolog Christian Pfeifer, prema podatcima Petra Seewalda, ne slaže se s medijskim izvještajima te ističe da je $0,1 \%$ zlostavljača među suradnicima i službenicima Katoličke crkve. Kada netko svoje istrage i pisanje usredotoči samo na jednu skupinu, ostavlja izvan "dometa" i zakona i javnosti čak 99,9\% zlostavljača, upozorava Pfeifer. Ujedno time pokazuje da mu nije stalo do žrtava, nego je riječ o instrumentalizaciji tih slučajeva. Mediji u tom slučaju, kao i u brojnim drugima, slobodno možemo reći — nisu bez grijeha (Seewald prema Labaš et al., 2012, 280-281).

Nadalje, ne postoje druge opcije, nego transparentnost i iskrenost. Kako je već spomenuto, nakon skandala svećeničkoga seksualnoga zlostavljanja maloljetnika u Irskoj, papa Benedikt XVI. poručio je svećenicima: »Jedino odlučno, transparentno i pošteno djelovanje može vratiti poštovanje i dobrohotnost Iraca prema Crkvi. To mora proizići, prije svega, iz vlastitoga preispitivanja, unutarnjega pročišćavanja i duhovne obnove« (Benedikt XVI., 2010b). Konačno, crkveni poglavari iz takvih kriza mogu naučiti kako se zaštita djece i mladih mora uvrstiti na popis prioriteta crkvenoga djelovanja, što je na razini Crkve i učinjeno osnivanjem posebnoga tijela. Naime, papa Franjo je 22. ožujka 2014. uspostavio Papinsku komisiju za zaštitu maloljetnika, čija je zadaća Svetomu Otcu predlagati najprikladnije inicijative za zaštitu maloljetnika i odraslih žrtava zlostavljanja. Komisija je također pozvana poduzeti sve napore kako se zločini seksualnoga zlostavljanja u Crkvi ne bi ponovili (Franjo, 2014).

Predsjednik odbora unutar Kongregacije za nauk vjere koji se bavi žalbama podnesenim od strane svećenika optuženih za zlostavljanje malteški nadbiskup Charles Scicluna vjeruje da za Crkvu takvi skandali »mogu biti prilika za poniznost« (Anon., 2018). Važno je, također, ne zanemariti činjenicu da je riječ o grijehu i zlu koje je počinjeno prema pojedincu, ali i cjelokupnoj zajednici. Ne smije se zaboraviti da zlostavljači moraju snositi posljedice te da crkveni poglavari u svojoj odgovornosti moraju djelovati sukladno svojim ovlastima i kanonskomu pravu. Naime, nakon proglašenja važećega Zakonika kanonskoga prava papa Ivan Pavao II. je 30. travnja 2001., u obliku motuproprija Sacramentorum 
sanctitatis tutela (Normae de gravioribus delictis Congregationi pro Doctrina Fidei reservatis), »precizno odredio najteža kažnjiva djela protiv ćudoređa i u slavljenju sakramenata koja su u isključivoj mjerodavnosti Kongregacije za nauk vjere, kao i posebne procesne norme za proglašenje ili izricanje kanonskih kaznenih mjera « (Šalković, 2012, 365).

\section{Zaključak}

U kulturi transparentnosti, kojoj danas svjedočimo, skandali i loše vijesti ne mogu biti stavljene "pod tepih". Katoličkoj crkvi trebalo je mnogo vremena da shvati kako skandali postoje i da ih se ne smije ignorirati. U suprotnom, loše upravljanje kriznim situacijama u Crkvi može rezultirati dodatnom sekularizacijom i netrpeljivosti prema religiji.

Kada kriza nastupi, postoje tri pravila koja je Crkva kao institucija pozvana slijediti: govoriti istinu, biti ponizan i biti dobro pripremljen. To potonje dovodi do zaključka da bi svaka biskupija na organizacijskoj razini trebala imati specijalizirani odjel za komunikaciju u kriznim situacijama te izrađen i unaprijed pripremljen krizni komunikacijski plan. Ukratko, krizna komunikacija mora biti vođena profesionalnim načelima.

Prema naputcima crkvenoga učiteljstva, u tim specijaliziranim odjelima krizni tim čine laici (profesionalni komunikatori s visokim kompetencijama i vještinama), koji su odgovorni za planiranje i implementiranje komunikacijskih strategija. Usto, misija je takvih komunikatora kreativna obrada religijskih tema i razvijanje strategija za promociju kulturalnih promjena.

Crkvi je nasušno potreban takav laikat koji će odgovoriti na izazove suvremenih globalizacijskih trendova i komunikacijske revolucije 21. stoljeća. Laikat koji, kao što kaže papa Franjo, ima viziju budućnosti, koji nije zatvoren u malenosti života, laikat sa životnim iskustvom, koji ne prestaje sanjati (Franjo, 2016).

\section{Literatura}

Allen, John L. (2015). The Francis Miracle: Inside the Transformation of the Pope and the Church. New York: Time books.

Anon. (2013). Book probes paedophilia in Polish Church. Radio Poland, 1. veljače 2013. URL: http://archiwum.thenews.pl/1/9/Artykul/125979 (13. travnja 2020.) [Potpisano: nh.]

Anon. (2018). Archbishop Scicluna: Sexual abuse is a tragedy that will make us more humble. Rome Reports, 8. listopada 2018. URL: https://www.romereports.com/ en/2018/10/08/archbishop-scicluna-sexual-abuse-is-a-tragedy-that-will-make-usmore-humble/ (15. travnja 2020.)

Benedikt XVI. (2010a). Pastoral letter of the Holy Father Benedict XVI to the Catholics of Ireland. The Holy See. URL: http://w2.vatican.va/content/benedict-xvi/en/ letters/2010/documents/hf_ben-xvi_let_20100319_church-ireland.html (13. travnja 2020.)

Benedikt XVI. (2010b). Svjetlo svijeta. Split: Verbum. 
Benedikt XVI. (2012). Kateheza pape Benedikta XVI. na općoj audijenciji: Srijeda, 30. svibnja 2012. The Holy See. URL: http://www.vatican.va/content/benedict-xvi/hr/audiences/2012/documents/hf_ben-xvi_aud_20120530.html (13. travnja 2020.)

Bordoni, Linda (2018). Chilean bishops implore forgiveness for sex abuse scandal and offer to resign. Vatican News, 18. svibnja 2018. URL: https://www.vaticannews.va/ en/vatican-city/news/2018-05/chile-bishops-statement-resignation-sex-abuse.html (13. travnja 2020.)

Broom, Glen M. (2010). Učinkoviti odnosi s javnošću. Zagreb: Mate.

Centofanti, Sergio; Žaja, Mate (2018). Crkva u Njemačkoj: Predstavljena studija o zlostavljanjima u Katoličkoj Crkvi. Vatican News, 1. listopada 2018. URL: https://www. vaticannews.va/hr/crkva/news/2018-10/crkva-njemacka-studija-zlostavljanja.html (13. travnja 2020.)

CIC. Codex Iuris Canonici. Ivan Pavao II., Zakonik kanonskoga prava. Zagreb: Glas Koncila, 1996.

Cierva, Yago de la (2014). La Chiesa casa di vetro: Proposte ed esperienze di comunicazione nel contesto di crisi e controversie mediatiche. Roma: EDUSC.

Commission of Investigation (2009). Report by Commission of Investigation into Catholic Archdiocese of Dublin. Department of Justice and Equality. URL: http://www.justice. ie/en/JELR/Pages/PB09000504 (13. travnja 2020.)

Franjo (2014). Chirograph of His Holiness Pope Francis for the Institution of a Pontifical Commission for the Protection of Minors. The Holy See. URL: https://w2.vatican.va/ content/francesco/en/letters/2014/documents/papa-francesco_20140322_chirografo-pontificia-commissione-tutela-minori.html (15. travnja 2020.)

Franjo (2016). Address of His Holiness Pope Francis to participants in the Plenary Assembly of the Pontifical Council for the Laity. The Holy See. https://w2.vatican.va/ content/francesco/en/speeches/2016/june/documents/papa-francesco_20160617_plenaria-pc-laici.html (15. travnja 2020.)

Franjo (2019). Papa, Address of His Holiness Pope Francis at the end of the Eucharistic Concelebration. The Holy See. URL: http://w2.vatican.va/content/francesco/en/ speeches/2019/february/documents/papa-francesco_20190224_incontro-protezioneminori-chiusura.html (14. travnja 2020.)

Hermida, Alfred (2012). Social journalism: Exploring how social media is shaping journalism. U: Eugenia Siapera i Andreas Veglis (ur.), The Handbook of Global Online Journalism (str. 309-328). Oxford: Wiley-Blackwell.

Hrvatska biskupska konferencija (2006). Crkva i mediji: Pastoralne smjernice. Zagreb. URL: http://hbk.hr/wp-content/uploads/2018/11/2006-crkva_i_mediji.pdf (15. travnja 2020.)

Institute for Crisis Management (2018). The ICM Annual Crisis Report. Institute for Crisis Management. URL: https://crisisconsultant.com/icm-annual-crisis-report/ (14. travnja 2020.)

Jugo, Damir (2017). Menadžment kriznog komuniciranja. Zagreb: Školska knjiga

La Porte, José María (2009). Introduzione alla Comunicazione Istituzionale della Chiesa. Roma: EDUSC.

Labaš, Danijel; Kanižaj, Igor; Ciboci, Lana (2012). Medijsko izvještavanje o zlostavljanjima u katoličkim odgojnim ustanovama u Irskoj. Riječki teološki časopis, 38(2)2, 279-312.

Luecke, Richard (2005). Upravljanje kriznim situacijama: Svladajte vještine i spriječite katastrofu. Zagreb: Harvard Business Essentials. 
McGarry, Patsy (2016). Mass attendance in Dublin to drop by one-third by 2030. The Irish Times, 21. siječnja 2016. URL: https:/www.irishtimes.com/news/social-affairs/ religion-and-beliefs/mass-attendance-in-dublin-to-drop-by-one-third-by-20301.2504351 (13. travnja 2020.)

Milas, Dorotea; Galić, Goran (2014). Krizno komuniciranje i medijska percepcija Crkve u slučaju odreknuća pape Benedikta XVI. U: Siniša Tatalović (ur.), Dani kriznog upravljanja. (str. 767-784). Velika Gorica: Veleučilište Velika Gorica.

Novak, Božidar (2001). Krizno komuniciranje i upravljanje opasnostima. Zagreb: Binoza.

Papinsko vijeće za komunikaciju (1992). Pastoral instruction "Aetatis novae" on social communications on the twentieth anniversary of Communio et progressio. The Holy See. URL: https://www.vatican.va/roman_curia/pontifical_councils/pccs/documents/ rc_pc_pccs_doc_22021992_aetatis_en.html (14. travnja 2020.)

Public Relations Society of America (s. a.). PRSA Code of Ethics. PRSA. URL: https:// www.prsa.org/about/ethics/prsa-code-of-ethics (15. travnja 2020.)

Puškarić, Borna (2015). The role of the diocesan spokesperson in time of crisis (Licencijatski rad). Fakultet crkvene komunikacije, Papinsko učilište Sveti križ, Rim.

Richardson, Neil; Laville, Lucy (2010). Develop Your PR Skills. London: Kogan Page.

Sarah, Robert; Diat, Nicolas (2016). Bog ili ništa: Razgovor o vjeri. Zagreb: Kršćanska sadašnjost.

Shotter, James; Huber Evon (2019). Catholic Church: paedophilia scandal dents Poland's faith. Financial Times. URL: https://www.ft.com/content/b38f994c-8dc2-11e9-a24db42f641eca37 (16. travnja 2020.)

Skoko, Božo; Gusić, Valentina (2013). Novi mediji u službi evangelizacije i u životu župne zajednice - primjena u župama Zagrebačke nadbiskupije. Nova prisutnost, 11(2), 193-213.

Šalković, Josip (2012). Kažnjiva djela protiv posebnih obveza (kann. 1392-1396). Riječki teološki časopis, 38(2), 353-378.

Šola, Ivica (2014). Zaštitimo djecu od "zaštitnika djece”! Laudato.hr, 8. veljače 2014. URL: http://www.laudato.hr/Kolumne/Prvi-petak/Zastitimo-djecu-od-zastitnikadjece-!.aspx (15. travnja 2020.)

Tagliabue, John (2002). Pope Accepts Polish Archbishop's Resignation. The New York Times, 29. ožujka 2002. URL: https://www.nytimes.com/2002/03/29/world/popeaccepts-polish-archbishop-s-resignation.html (13. travnja 2020.)

Tiskovni ured Zagrebačke nadbiskupije (2011). Priopćenje Zagrebačke nadbiskupije vezano uz slučaj pokretanja istražnih radnji nad svećenikom. Zagrebačka nadbiskupija, 20. listopada 2011. URL: http://zg-nadbiskupija.hr/default.aspx?id=7157 (13. travnja 2020.)

Tomić, Zoran (2008). Odnosi s javnošću: Teorija i praksa. Zagreb: Synopsis.

Trbušić, Davor; Labaš, Danijel (2015). Strategije i izazovi crkvene komunikacije: Tiskovni ured Zagrebačke nadbiskupije. U: Dejan Verčić, Damir Jugo i Lana Ciboci (ur.), Reconciling the Traditional and Contemporary. The New Integrated Communication (str. 143-158). Zagreb: Edward Bernays College of Communication Management.

Ujedinjeni narodi (1996). Status of the Convention on the Rights of the Child: Report of the Secretary-General. Ujedinjeni narodi. URL: http://www.un.org/documents/ga/ docs/51/plenary/a51-424.htm (23. studenoga 2017.)

Wilcox, Dennis L.; Cameron, Glen T.; Reber, Bryan H. (2012). Public Relations: Strategies and Tactics. Boston: Allyn \& Bacon. 
Winfield, Nicole (2014). Vatican comes under sharp criticism for sex abuse. U. S. News, 16. siječnja 2014. URL: https://www.usnews.com/news/world/articles/2014/01/16/vatican-acknowledges-no-excuse-for-child-abuse (13. travnja 2020.)

World Organization Against Torture (2014). Unofficial minutes of the Committee Against Torture's 52nd session - Holy See review. Child Rights International Network. URL: http://www.omct.org/files/2014/05/22677/holyseecatreview_crinandomctnotes. pdf (13. travnja 2020.)

Zadarska nadbiskupija (2014). Utvrđena kaznena odgovornost don Nedjeljka Ivanova Priopćenje Zadarske nadbiskupije. Zadarska nadbiskupija, 21. veljače 2014. URL: http://www.zadarskanadbiskupija.hr/?p=11739 (13. travnja 2020.)

Zgrabljić Rotar, Nada (2011). Digitalno doba: Masovni mediji i digitalna kultura. Zadar: Sveučilište u Zadru.

\section{Crisis Management in the Catholic Church: The Challenges of Institutional} Communication

Davor Trbušić*

\section{Summary}

The resignation of Pope Benedict XVI, scandals such as cases of sexual abuse by priests in Ireland, the USA and Australia, Vatileaks, or issues linked to the lack of financial transparency, brought to the surface the need for professional crisis communication within the organisation of the Catholic Church. The author believes that operational departments in charge of communication at the organisational level of the Church must seek more effective ways of confronting crisis situations. By relying on contemporary crisis management concepts with an action-oriented perspective, ecclesiastic communicators must embrace the mindset of strategic thinking in order to dismiss prejudices about crises often inherent to Church leaders and must follow specific tactics so as to mitigate the crisis situation. Above all, truthfulness must be the conditio sine qua non of successful crisis management. This paper demonstrates that bishops need to adopt a culture based on accountability, but also to rethink times of crisis and transform them into an opportunity to communicate the Gospel.

Key words: crisis management; Catholic Church; ecclesiastic communication

* Davor Trbušić, mag. comm, University Department of Croatian Studies, University of Zagreb. Address: Borongajska cesta 83d, 10000 Zagreb, Croatia. E-mail:dtrbusic@hrstud.hr 